\title{
Prevalence and experimental transmission of the steelhead herpesvirus in salmonid fishes
}

\author{
William D. Eaton ${ }^{1, *}$, William H. Wingfield ${ }^{2}$, Ronald P. Hedrick ${ }^{3}$ \\ ${ }^{1}$ Juneau Center for Fisheries and Ocean Sciences, University of Alaska, Fairbanks, 11120 Glacier Highway, Juneau, Alaska \\ 99801 , USA \\ ${ }^{2}$ Fish Disease Laboratory, California Department of Fish and Game, Rancho Cordova, California 95607, USA \\ ${ }^{3}$ Aquaculture Program, Department of Medicine, School of Veterinary Medicine, University of California, Davis, California \\ 95616, USA
}

\begin{abstract}
Steelhead herpesvirus (SHV) was isolated from $5.8 \%$ of the ovarian fluids of female steelhead trout Oncorhynchus mykiss returning to the Warm Springs Hatchery, Geyserville, California, from January through April 1986, and has currently been isolated from steelhead or rainbow trout $O$. mykiss from 7 hatcheries and 2 lakes in California. Following injection, the virus replicated in rainbow trout and chinook salmon 0 . tshawytscha, but not in coho salmon $O$. kisutch or brown trout Salmo trutta. The virus was also transmitted to steelhead and rainbow trout by waterborne exposures. In laboratory experiments. SHV induced only minor histopathologic changes in rainbow trout liver; the most prominent being hepatocyte syncytia which contain Feulgen positive, eosinophilic Cowdry Type A inclusions.
\end{abstract}

\section{INTRODUCTION}

In 1985, a herpesvirus, designated SHV, was isolated from ovarian fluids of adult female steelhead trout Oncorhynchus mykiss returning to the Warm Springs Hatchery in Geyserville, California (Hedrick et al. 1986). The virus induced formation of syncytia in chinook salmon embryo (CHSE-214) and rainbow trout gonad (RTG-2) cell lines, following a 3 to $4 \mathrm{wk}$ incubation period at $10^{\circ} \mathrm{C}$.

Hedrick et al. (1987) showed that SHV shared morphologic characteristics with the 4 previously isolated salmonid herpesviruses, Oncorhynchus Masou virus (OMV), Yamame Tumor virus (YTV), Nerka Virus (from Towada Lake, Amori Prefecture) (NeVTA), and Herpesvirus salmonis (HPV), but, in serum cross neutralization tests, it was most related to HPV. Because the 4 other herpesviruses are pathogenic to salmonids (Wolf et al. 1975a, b, Sano 1976, Kimura et al. 1981. Sano et al. 1983), SHV was extensively studied to determine its potential impact on salmonid populations in California.

\footnotetext{
- Addressee for correspondence
}

\section{MATERIALS AND METHODS}

Cell lines, viruses and fish. The CHSE-214 cell line (ATCC CRL 1681) used throughout this study was cultured in Corning tissue culture flasks containing Eagle's Minimum Essential Medium (EMEM), supplemented with Earle's salts, $2 \mathrm{mM}$ L-glutamine, $50 \mu \mathrm{g}$ $\mathrm{ml}^{-1}$ streptomycin, $50 \mathrm{IU} \mathrm{ml}^{-1}$ penicillin and either 0 , 2, or $5 \%$ (EMEM-0, EMEM-2, EMEM-5, respectively) fetal bovine serum.

The SHV used in this study was isolated from adult steelhead trout in 1985 and had been passaged 4 times in tissue culture and then stored at $-80^{\circ} \mathrm{C}$. Prior to each experiment, an aliquot of the virus was thawed, passaged once in tissue culture, and $1 \mathrm{ml}$ of the virus supernatant intraperitoneally injected into $20 \mathrm{~g}$ rainbow trout which were held in $10^{\circ} \mathrm{C}$ water for $2 \mathrm{wk}$. The virus was isolated from these fish by inoculation of liver and kidney homoenates onto CHSE-214 cells as described below. The isolated virus was then used immediately for the different experiments and titrated using standard $\mathrm{TCID}_{50}$ assay procedures (Hedrick et al 1978) to ascertain the amount of virus employed for each study. 
All fish used for the in vivo challenges were supplied by the California Department of Fish and Game Quarantine Facility, Yountville, California. All fish were certified as virus-free prior to the experiments.

Viral examination. Ovarian fluid samples were collected from 255 mature female steelhead trout returning to the Warm Springs Hatchery between January and April 1986. Samples were centrifuged 15 min at $2000 \times g$ to remove cell debris, then each supernatant was diluted $1: 2(\mathrm{v} / \mathrm{v})$ with antibiotic solution (initial concentration of $0.5 \mathrm{mg} \mathrm{ml}^{-1}$ gentamicin, $1 \mathrm{mg} \mathrm{ml}^{-1}$ steptomycin, $50 \mathrm{IU} \mathrm{ml^{-1 }}$ penicillin, $25 \mu \mathrm{g} \mathrm{ml}-1$ fungizone) and incubated overnight at $5^{\circ} \mathrm{C}$. Because HPV was associated with post-spawning mortalities of rainbow trout at the Winthrop Hatchery in Washington State (Wolf \& Taylor 1975), 44 female fish, spawned on either 13 February 1986, 27 February 1986, 6 March 1986, or 13 March 1986 (10 to 12 fish $\mathrm{d}^{-1}$ ) were held in hatchery water for 3 wk and then samples of liver, kidney and spleen were collected and individually examined for virus.

Tissues were diluted 1:2 (w/v) with antibiotic solution, disrupted in a Polytron Cell Disrupter (Brinkmann Instruments), and incubated overnight at $5^{\circ} \mathrm{C}$. Following overnight incubation, ovarian fluid and tissue samples were centrifuged $15 \mathrm{~min}$ at $2000 \times g$ and the supernatant fluids collected. Replicate $0.2 \mathrm{ml}$ aliquots of supernatant from each sample were then inoculated into wells of a 24-well plate (Falcon Laboratories) containing monolayer cultures of CHSE-214 cells. This resulted in a final dilution of $1: 10$ for both the tissue homogenates $(w / v)$ and the ovarian fluids (v/v). Samples were incubated for $1 \mathrm{~h}$ at $10^{\circ} \mathrm{C}$ and $0.8 \mathrm{ml}$ EMEM5 was then added to each well. Samples were then incubated at $10^{\circ} \mathrm{C}$ and examined weekly for CPE. If no CPE was present after $4 \mathrm{wk}$, cells and culture fluid were removed from the culture plates and inoculated onto fresh monolayers of CHSE-214 cells. A sample was considered negative if 2 such passages resulted in no CPE.

Viral isolates obtained from ovarian fluid and tissue samples showing herpesvirus-like CPE were compared by neutralization assay to the original isolate of SHV from 1985 (supplied by Dr W. H. Winfield, Californian Dept. of Fish and Game) and also to HPV (supplied by Dr T. Kimura, Faculty of Fisheries, Hokkaido Univ., Hakodate, Japan). Anti-SHV and Anti-HPV antisera were prepared and the neutralization assays were performed as described by Okamoto et al. (1983).

Host range. To determine the potential host range of SHV, each of 50 juvenile chinook ( $48 \mathrm{~mm}, 0.9 \mathrm{~g}$ ), coho salmon (62 mm, $1.3 \mathrm{~g})$, brown (53 mm, $0.9 \mathrm{~g})$ and rainbow trout $(56 \mathrm{~mm}, 1.0 \mathrm{~g})$ received intraperitoneal injections of $10^{32} \mathrm{TCID}_{50}$ of SHV. Another 50 fish of each species were injected with $0.1 \mathrm{ml}$ EMEM-0 with- out virus as controls. Each group of fish was held in separate $20 \mathrm{l}$ aquaria for $6 \mathrm{wk}$, receiving well water with a mean temperature of $10.6^{\circ} \mathrm{C}$ (range of $9^{\circ}$ to $14^{\circ} \mathrm{C}$ ). Each week, pooled samples of liver, kidney, and pancreas were collected from 3 fish of each species and examined for virus. Sampling began at $2 \mathrm{wk}$ postinjection and continued until $6 \mathrm{wk}$ postinjection. Tissues were processed as described above and the concentration of SHV determined using a standard TCID $_{50}$ assay (Hedrick et al. 1978). An additional 3 fish from each species were collected weekly for histologic examination.

Effect on 2 sizes of rainbow trout. One hundred alevin $(10 \mathrm{~mm}, 0.1 \mathrm{~g})$ and 100 juvenile $(40 \mathrm{~mm}, 0.2 \mathrm{~g})$ rainbow trout were exposed to either $10^{2.7} \mathrm{TCID}_{50} \mathrm{ml}^{-1}$ of Sirv fiesi gruupj oi âr equal volume of EMIEM-O without virus (control group) in $1.5 \mathrm{l}$ of $9^{\circ} \mathrm{C}$ well water for $2 \mathrm{~h}$. Following this, fish were held in $9^{\circ}$ to $11^{\circ} \mathrm{C}$ water in $20 \mathrm{l}$ aquaria. The numer of fish was adjusted so that the weight of fish per volume of water was approximately equal in the 2 experiments. Fish were sampled weekly for $6 \mathrm{wk}$, beginning at $2 \mathrm{wk}$ postexposure. Alevins were also sampled at 20 and $35 \mathrm{wk}$, and juvenile fish at 16 and $31 \mathrm{wk}$ postexposure. The concentration of SHV in all fish was determined as described above with the exception that whole fish rather than organs were pooled. Five fish were fixed in $10 \%$ buffered formalin; 2 of these were examined for histopathologic evidence of viral infection, and 3 for the presence of viral DNA (as described below).

Effect on chinook salmon. One hundred alevin $(30$ $\mathrm{mm}, 0.2 \mathrm{~g}$ ) chinook salmon were exposed to either $10^{3}$ TCID $_{50} \mathrm{ml}^{-1}$ of SHV (test group) or an equal volume of EMEM-O (control group) in 1.51 of $8^{\circ} \mathrm{C}$ well water for 2 $\mathrm{h}$, then maintained in water at $7^{\circ}$ to $9^{\circ} \mathrm{C}$ in $20 \mathrm{I}$ aquaria. Fish were sampled weekly from 1 wk through 6 wk and again at 10 wk postexposure. The concentration of virus in the liver, kidney, and pancreas of 5 fish was individually determined as described above. Three fish were fixed in $10 \%$ buffered formalin and examined for the presence of viral DNA, as described below, and 2 fish were fixed in Davidson's solution (Humason 1979) and used for histopathologic analysis.

Detection of viral DNA in liver, kidney, and pancreas. Liver, kidney, and pancreas of fish collected for the previously described experiments were examined for viral DNA using a ${ }^{3} \mathrm{H}-\mathrm{SHV}$-DNA probe and a modification of the hybridization techniques of Brandsma \& Miller (1980) and Maniatis et al. (1982). The technique is described in detail by Eaton (1988). Briefly, $0.2 \mathrm{~g}$ of fish tissue was fixed in $10 \%$ buffered formalin, then incubated for $16 \mathrm{~h}$ in $1.0 \mathrm{ml}$ of buffer $(0.2 \mathrm{M}$ Tris- $\mathrm{HCl}$, $0.1 \mathrm{M}$ EDTA, $\mathrm{pH} 8.5$ ) at $5^{\circ} \mathrm{C}$. Following sonication of tissues, $0.5 \mathrm{ml}$ of the cell suspension was mixed with 0.5 $\mathrm{ml}$ of $1.0 \mathrm{M} \mathrm{NaOH}$. Twenty microliters of the mixture 
Table 1. Onchorhynchus mykiss. Prevalence of steelhead herpesvirus (SHV) in ovarian fluids or visceral tissues of adult steelhead trout returning to the Warm Springs Hatchery in 1986. CHSE-214 cells were inoculated with ovarian fluid (diluted 1:10 v/v) taken at the time of spawning, and incubated at $10^{\circ} \mathrm{C}$. Liver, kidney and spleen were collected from adult female fish held at the hatchery for $3 \mathrm{wk}$ postspawning. Tissues were pooled prior to viral examination

\begin{tabular}{|c|c|c|c|c|c|c|}
\hline \multirow[t]{2}{*}{ Date } & \multicolumn{3}{|c|}{ Ovarian fluid samples } & \multicolumn{3}{|c|}{ Visceral tissues } \\
\hline & No. sampled & No. pos. & $\%$ Pos. & No. sampled & No. pos. & $\%$ Pos. \\
\hline $31 \mathrm{Jan}$ & 12 & 2 & 16.6 & ND & ND & ND \\
\hline 6 Feb & 50 & 0 & 0.0 & ND & ND & ND \\
\hline 13 Feb & 33 & 1 & 3.0 & 11 & 0 & 0.0 \\
\hline 27 Feb & 50 & 1 & 2.0 & 10 & 1 & 10.0 \\
\hline 6 Mar & 40 & $5^{a}$ & 12.5 & 12 & 1 & 8.3 \\
\hline 13 Mar & 40 & 0 & 0.0 & 11 & 0 & 0.0 \\
\hline 27 Mar & 40 & $6^{\mathrm{b}}$ & 200 & ND & ND & 0.0 \\
\hline Total & 255 & 15 & 5.8 & 44 & 2 & 4.5 \\
\hline \multicolumn{7}{|c|}{$\begin{array}{l}\text { a Two samples required } 2 \text { blind passages before expressing CPE } \\
\text { b Three samples required } 1 \text { blind passage before expressing CPE } \\
\text { ND: not done; Pos: positive }\end{array}$} \\
\hline
\end{tabular}

( $10^{5}$ to $10^{6}$ cells $\mathrm{ml}^{-1}$, as determined by hemacytometer) was heated to $100^{\circ} \mathrm{C}$ for $10 \mathrm{~min}$, chilled on ice, neutralized by the addition of $10 \mu$ l of buffer $1.0 \mathrm{M} \mathrm{NaCl}$, $0.3 \mathrm{M}$ sodium citrate, $0.5 \mathrm{M}$ Tris- $\mathrm{HCl}, \mathrm{pH} 8$, and $1.0 \mathrm{M}$ $\mathrm{HCl}$ ) and again chilled on ice.

Table 2. Onchorhynchus mykiss. Serologic comparisons of herpesvirus isolates recovered from the ovarian fluid or visceral tissues of adult steelhead trout from the Warm Springs Hatchery in 1986 to steelhead herpesvirus (SHV) and Herpesvirus salmonis (HPV). Antiserum titer expressed as the reciprocol of the $50 \%$ endpoint of the antiserum neutralizing titer.

Amount of virus used in each test, expressed as TCID 50

\begin{tabular}{|c|c|c|c|c|}
\hline \multirow[t]{2}{*}{ Sample } & \multirow{2}{*}{$\begin{array}{l}\text { Date } \\
\text { collected }\end{array}$} & \multirow{2}{*}{$\begin{array}{l}\text { Amount } \\
\text { virus }\end{array}$} & \multicolumn{2}{|c|}{ Antiserum Titer } \\
\hline & & & Anti-SHV & Anti-HPV \\
\hline \multicolumn{5}{|c|}{ Ovarian fluid } \\
\hline & $13 \mathrm{Feb}$ & 42 & 112 & 115 \\
\hline & $27 \mathrm{Feb}$ & 63 & 165 & 130 \\
\hline & $6 \mathrm{Mar}$ & 32 & 122 & 118 \\
\hline & $6 \mathrm{Mar}$ & 79 & 105 & 96 \\
\hline & $6 \mathrm{Mar}$ & 130 & 133 & 106 \\
\hline & 6 Mar & 100 & 153 & 128 \\
\hline & 6 Mar & 257 & 116 & 125 \\
\hline & $28 \mathrm{Mar}$ & 159 & 138 & 143 \\
\hline & $28 \mathrm{Mar}$ & 79 & 125 & 102 \\
\hline & $28 \mathrm{Mar}$ & 275 & 85 & 96 \\
\hline & $28 \mathrm{Mar}$ & 360 & 108 & 112 \\
\hline & $28 \mathrm{Mar}$ & 63 & 111 & 107 \\
\hline & $28 \mathrm{Mar}$ & 372 & 142 & 119 \\
\hline \multicolumn{5}{|c|}{ Visceral tissues } \\
\hline & 27 Feb & 320 & 75 & 93 \\
\hline & $6 \mathrm{Mar}$ & 42 & 127 & 116 \\
\hline \multicolumn{5}{|l|}{ Control } \\
\hline HPV & & 100 & 142 & 120 \\
\hline SHV & & 159 & 110 & 90 \\
\hline
\end{tabular}

Nitrocellulose filter paper (BioRad Laboratories) was pretreated according to the procedures of Maniatis et al. (1982), then spotted with replicate $10 \mu$ aliquots of each different sample. The remaining prehybridization, hybridization, washing procedures and solutions were identical to those of Maniatis et al. (1982) except that the prehybridization and hybridization temperature was $42^{\circ} \mathrm{C}$ rather than $68^{\circ} \mathrm{C}$ and 33000 counts per minute (CPM) of ${ }^{3} \mathrm{H}$-SHV DNA was used as the probe, rather than $10^{5}$ to $10^{6} \mathrm{CPM}$ of cloned DNA. Prehybridization occurred for $3 \mathrm{~h}$ and hybridization for $24 \mathrm{~h}$. Following hybridization and washing, each piece of nitrocellulose was placed into a separate scintillation vial, mixed with $1.0 \mathrm{ml}$ Ready Solv-EP scintillation cocktail (Beckman Co.) and the CPM of ${ }^{3} \mathrm{H}-\mathrm{SHV}$ DNA determined using a Packard 2000 TriCarb liquid scintillation analyzer (United Technologies).

Histologic procedures. Whole fish were fixed in $10 \%$ buffered formalin or Davidson's solution for $24 \mathrm{~h}$ then transferred to $70 \%$ ethanol. Following standard dehydration and clearing procedures (Humason 1979), fish were embedded in paraffin and sections of 7 to 8 $\mu \mathrm{m}$ thickness were then stained with hematoxylin and eosin (H\&E). The sections were examined and photographed using an Olympus BH2 light microscope.

\section{RESULTS}

\section{Viral examination}

Virus was detected in 15 of $255(5.8 \%)$ ovarin fluid samples and in 2 of $44(4.5 \%)$ pooled tissue samples from steelhead trout at the Warm Springs Hatchery (Table 1). All virus isolates recovered were neutralized 
(50\% endpoint) by $1 \cdot 75$ to $1 \cdot 165$ dilutions of anti-SHV or anti-HPV antisera. These dilutions of antisera were comparable to those required $(1: 90$ to $1: 142)$ to achieve $50 \%$ neutralization of approximately the same concentration of the control viruses SHV and HPV (Table 2)

\section{Host range}

No mortalities occurred in brown trout or coho salmon injected with SHV and no virus was isolated from either of these species. No mortalities occurred in rainbow trout or chinook salmon injected with SHV but virus was isolated from both species. The concentrations of SHV in chinook salmon ranged from $10^{1.0}$ to $10^{3.3}$ TCID $_{50} \mathrm{~g}^{-1}$, while those in rainbow trout ranged from $10^{1.8}$ to $10^{3.5} \mathrm{TCID}_{50} \mathrm{~g}^{-1}$ Maximum virus concentrations were found in both species at $3 \mathrm{wk}$ postexposure and no virus could be detected after $5 \mathrm{wk}$ in either species (Table 3). No virus was isolated from control fish

No histopathologic evidence of viral infection was observed in chinook salmon. Small focal areas of inflammation were seen in the liver or rainbow trout 4 to $5 \mathrm{wk}$ postexposure to the virus (Fig. 1.). These lesions were apparently transient because they were not seen after $5 \mathrm{wk}$ postexposure.

\section{Effect on 2 sizes of rainbow trout and chinook salmon}

At each sampling, virus was isolated from at least $40 \%$ of alevin and $20 \%$ of juvenile rainbow trout following waterborne exposure to SHV The highest mean concentrations of SHV in alevin $\left(10^{37} \mathrm{TCID}_{50}{ }^{-1}\right)$ and juvenile fish $\left(10^{2.9} \mathrm{TCID}_{50} \mathrm{~g}^{-1}\right)$ were detected at 4 wk postexposure. Virus was isolated from juvenile fish

Table 3. Concentrations of steelhead herpesvirus (SHV) in juvenile chinook and coho salmon and brown and rainbow trout following intraperitoneal injection with virus. SHV concentration determined by TCID 50 assay using pools of liver, kidney, and spleen from 3 fish. Values expressed as $\log _{10}$ $\operatorname{TCID}_{50} / \mathrm{g}^{-1}$ tissue. Lower limit of detection was $10^{1.6} \mathrm{TCID}_{50}$ $\mathrm{g}^{-1}$ tissue. -: No virus detected; W 1-6: weeks postinjection with SHV

\begin{tabular}{lcccccccc|}
\hline \multirow{2}{*}{ Fish species } & \multicolumn{7}{c|}{ SHV Concentrations } \\
& W 1 & W 2 & W 3 & W 4 & W 5 & W 6 \\
\hline Chinook salmon & 1.9 & 2.5 & 3.3 & 2.4 & 1.8 & - \\
$\begin{array}{l}\text { Coho salmon } \\
\text { Brown trout }\end{array}$ & - & - & - & - & - & - \\
Rainbow trout & 1.8 & 2.5 & 3.5 & 2.6 & 1.8 & - \\
\hline
\end{tabular}

as late as $16 \mathrm{wk}$ and from alevins as late as 20 wk postexposure but not thereafter (Table 4). No virus was isolated from control fish

Virus was isolated from at least $20 \%$ of the samples collected from chinook salmon alevins following waterborne exposure to SHV. The highest mean virus concentrations $\left(10^{3.8} \mathrm{TCID}_{50} \mathrm{~g}^{-1}\right)$ were detected at 4 and 5 wk postexposure to the virus. Virus was isolated at the last sampling (10 wk postexposure) of these fish (Table 4). No virus was isolated from control fish.

No histopathologic evidence of viral infection was seen in alevin chinook salmon exposed to SHV. Focal areas of inflammation were observed in the liver of juvenile rainbow trout $31 \mathrm{wk}$ postexposure to SHV (Fig. 1). At $6 \mathrm{wk}$ postexposure, focal areas of hepatocyte syncytia were observed in alevin rainbow troui liver. These fused liver cells had enlarged nuclei containing Feulgen positive, eosinophilic Cowdry Type A inclusion bodies (Fig. 1).

\section{Viral DNA in liver, kidney and pancreas}

Maximal concentrations of SHV-DNA in liver, kidney, and pancreas $(214,44$, and 137 ng SHV-DNA 0.2 $\mathrm{g}^{-1}$, respectively) of rainbow trout alevins was detected at 4 or 5 wk postexposure to the virus. Viral DNA was present at 20 but not $35 \mathrm{wk}$ postexposure (Table 5). The greatest concentration of viral DNA in liver, kidney, and pancreas $\left(58,25\right.$, and $61 \mathrm{ng}$ SHV-DNA $0.2 \mathrm{~g}^{-1}$, respectively) of juvenile rainbow trout also was detected at 4 or 5 wk postexposure. Viral DNA could not be detected in these fish after the $16 \mathrm{wk}$ sample (Table 5). In chinook salmon alevins, maximal concentrations of SHV-DNA were detected in the liver, kidney, and pancreas $(151,42$, and 91 ng SHV-DNA 0.2 $\mathrm{g}^{-1}$, respectively) $5 \mathrm{wk}$ postexposure to the virus (Table 5)

\section{DISCUSSION}

Between January 1985 and July 1986 there was an alarming increase in the detection of a herpesvirus among adult steelhead and rainbow trout in 7 California state hatcheries (Warm Springs, Feather River, Mad River, Trinity River, Iron Gate, Shasta, and Mt Whitney) and 2 lakes (Eagle Lake and Junction Reservoir). In each instance, the virus did not induce any gross or histologic changes in the fish and took up to 3 or 4 wks to cause CPE on salmonid cells. All isolates appeared to be the same strain of virus ( $W$ H. Wingfield, unpubl. data).

In the current study, a representative isolate of these viruses, designated SHV, was shown to replicate slowly 

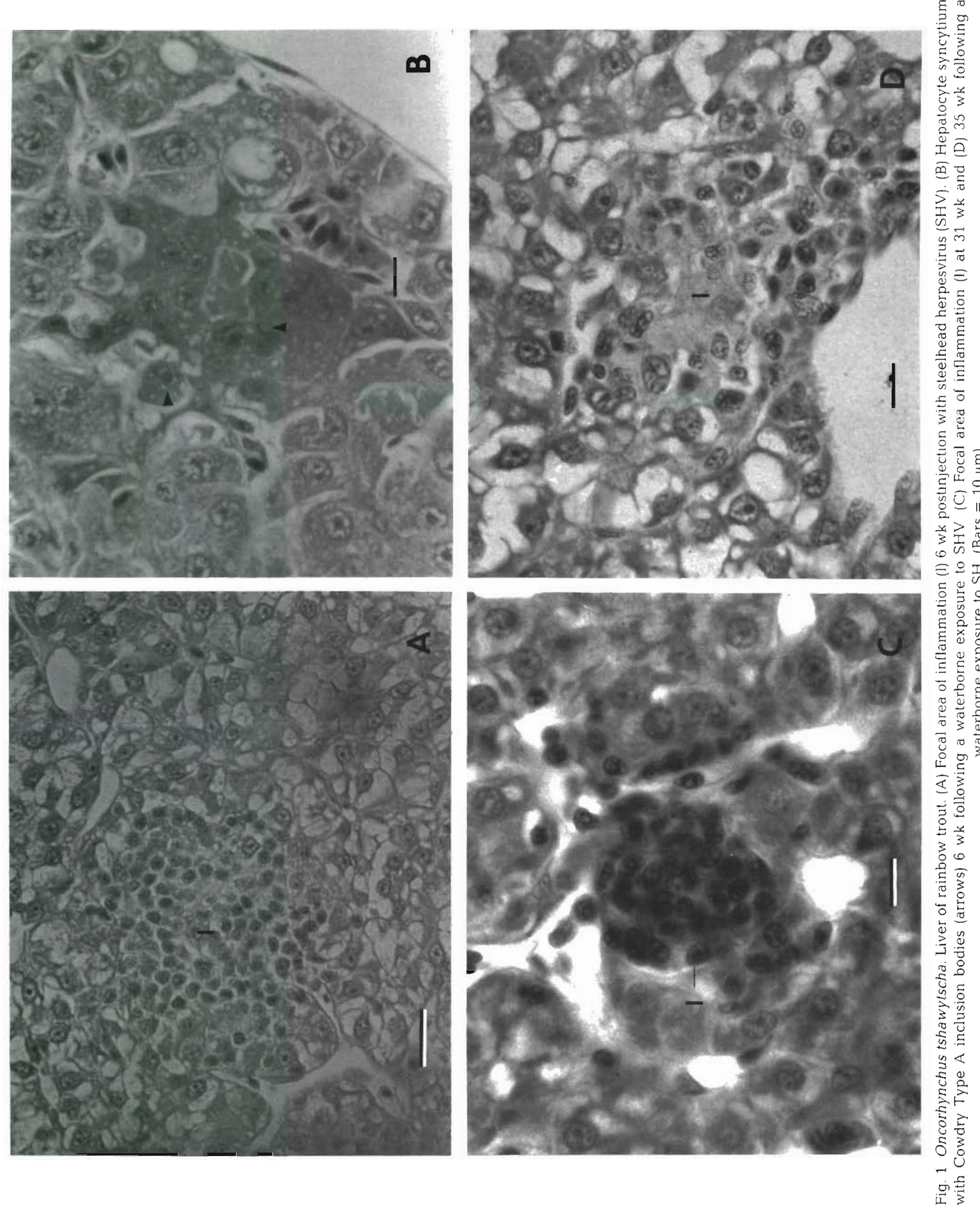
Table 4. Concentrations of steelhead herpesvirus (SHV) in alevin and juvenile rainbow trout and alevin chinook salmon following a waterborne exposure to virus. Five fish were sampled each week, and values expressed as $\log _{10} \mathrm{TCID}_{50} \mathrm{~g}^{-1}$ tissue. Lower limit of detection is $10^{1.6} \mathrm{TCID}_{50} \mathrm{~g}^{-1}$ tissue. Mean: geometric mean concentration of $\mathrm{SHV}_{\text {; }}-$ : no virus detected; Pos: positive

\begin{tabular}{|c|c|c|c|c|c|c|c|c|}
\hline \multirow{2}{*}{$\begin{array}{l}\text { Fish species } \\
\text { Rainbow trout }\end{array}$} & \multirow{2}{*}{$\begin{array}{c}\text { Postexposure } \\
\text { (wk) }\end{array}$} & \multirow{2}{*}{$\begin{array}{l}\text { No. fish } \\
\text { pos. }(\%) \\
2 / 5(40)\end{array}$} & \multicolumn{5}{|c|}{ SHV conc. } & \multirow{2}{*}{$\begin{array}{r}\text { Mean } \\
2.6\end{array}$} \\
\hline & & & 2.5 & 2.8 & - & - & - & \\
\hline \multirow[t]{6}{*}{ Alevins } & 3 & $3 / 5(60)$ & 3.1 & 2.6 & 3.0 & - & - & 2.9 \\
\hline & 4 & $4 / 5(80)$ & 3.9 & 3.6 & 3.8 & 3.4 & - & 3.7 \\
\hline & 5 & $3 / 5(60)$ & 3.4 & 3.2 & 3.0 & - & - & 3.2 \\
\hline & 6 & $2 / 5(40)$ & 2.7 & 2.9 & - & - & - & 2.8 \\
\hline & 20 & $2 / 5(40)$ & 2.4 & 2.3 & - & - & - & 2.4 \\
\hline & 35 & $0 / 5 \quad(0)$ & - & - & - & - & & 0.0 \\
\hline \multirow{7}{*}{$\begin{array}{l}\text { Rainbow trout } \\
\text { Juveniles }\end{array}$} & 2 & $1 / 5(20)$ & 2.1 & - & - & - & - & 2.1 \\
\hline & 3 & $1 / 5(20)$ & 2.5 & - & - & - & - & 2.5 \\
\hline & 4 & $3 / 5(60)$ & 2.6 & 3.2 & 3.0 & - & - & 2.9 \\
\hline & 5 & $2 / 5(40)$ & 2.5 & 3.1 & - & - & - & 2.8 \\
\hline & 6 & $2 / 5(40)$ & 2.5 & 2.7 & - & - & - & 2.6 \\
\hline & 16 & $1 / 5(20)$ & 2.2 & - & - & - & - & 2.2 \\
\hline & 31 & $0 / 5 \quad(0)$ & - & - & - & - & - & 0.0 \\
\hline \multirow{7}{*}{$\begin{array}{l}\text { Chinook salmon } \\
\text { Alevins }\end{array}$} & 1 & $1 / 5(20)$ & 2.2 & - & - & - & - & 2.2 \\
\hline & 2 & $2 / 5(40)$ & 2.2 & 2.1 & - & - & - & 2.2 \\
\hline & 3 & $2 / 5(40)$ & 3.2 & 2.1 & - & - & - & 2.7 \\
\hline & 4 & $3 / 5(60)$ & 3.9 & 4.0 & 3.5 & - & - & 3.8 \\
\hline & 5 & $3 / 5(60)$ & 3.8 & 3.7 & 4.0 & - & - & 3.8 \\
\hline & 6 & $2 / 5(40)$ & 2.8 & 2.6 & - & - & - & 2.7 \\
\hline & 10 & $1 / 5(20)$ & 2.7 & - & - & - & - & 2.7 \\
\hline
\end{tabular}

in both cell culture and in fish. The virus appeared to have low virulence for rainbow trout and chinook salmon but coho salmon and brown trout appeared to be refractory to it. The virus replicated, to a higher titer in alevin than in juvenile fish, which is also true of other fish herpesviruses such as channel catfish virus (Fijan 1968) and HPV (Wolf et al. 1975a, b). Infectious virus and viral DNA were detected in infected fish as late as 20 wk postexposure.

The liver appeared to be the principal target organ for SHV replication as evidenced by the high concentration of SHV-DNA in the liver, relative to the kidney and pancreas, of infected fish. This was further supported by the presence of focal areas of inflammation and syncytia observed in the livers of SHV-infected fish and the absence of lesions in the other organs examined. These syncytia contain intranuclear Feulgen positive, eosinophilic Cowdry Type A inclusion bodies often associated with herpesvirus infections in other animals (Roizman 1982).

The results of this study further show that SHV can infect fish by waterborne exposure, thus suggesting the potential for horizontal transmission. The presence of SHV in steelhead ovarian fluids and, more recently, in semen samples from male steelhead trout (W. H. Wingfield unpubl. data) also suggests that the possibility exists for vertical transmission of the virus.
Serological comparisons between SHV and the 4 other salmonid herpesviruses showed that SHV appears most related to HPV (Hedrick et al. 1987). Recently, the polypeptide compositions and DNA sequences of SHV and HPV were shown to be similar yet distinct from each other, and clearly distinct from OMV, YTV, and NeVTA (Eaton 1988). The results presented in the present study suggest there are also differences in the pathogenicity of SHV and HPV. Earlier studies showed that HPV could be transmitted to rainbow trout by injection of $10^{3}$ plaque forming units (PFU) of virus, but not through cohabitation exposures. Also, the virus induced significant mortalities and pathologic responses in infected fish (Wolf et al. 1975a, b, Wolf \& Smith 1981). In our study, SHV could be transmitted to fish by either injection or waterborne exposure to the virus, but it did not cause any mortalities and it induced only minor lesions in the liver.

Recognizing that the classification of salmonid herpesviruses remains unresolved, SHV appears to be more similar to HPV (Salmonid Herpesvirus Type 1) than to OMV (Salmonid Herpesvirus Type 2). However, based on the biochemical and serological differences and the differences in pathogenicity, it may be that SHV and HPV are 2 distinct, but closely related viruses.

The origin of SHV is not known, nor is it clear how long the virus has been present in California. Because 
Table 5. Concentrations of steelhead herpesvirus (SHV) DNA detected in tissues of alevin and juvenile rainbow trout and in alevin chinook salmon following waterborne exposure to virus. Counts per min (CPM) value represents the average of two $10 \mu \mathrm{l}$ samples originating from $0.2 \mathrm{~g}$ of tissue. SHV-DNA values are expressed as $\mathrm{ng} 0.2 \mathrm{~g}^{-1}$ tissue, calculated knowing that $4.0 \mu \mathrm{g}$ of pure SHVDNA when hybridized with $1.0 \mu \mathrm{g}{ }^{3} \mathrm{H}$-SHV probe, resulted in $13391 \mathrm{CPM}$. They were corrected for background activity of all reagents at the time of each assay. C: when CPM values in a sample were less than those in control sample, amount of viral DNA present in sample was considered to be $0 \mathrm{ng}$

\begin{tabular}{|c|c|c|c|c|c|c|c|}
\hline \multirow{2}{*}{$\begin{array}{l}\text { Fish } \\
\text { species }\end{array}$} & \multirow{2}{*}{$\begin{array}{c}\text { Postexposure } \\
\text { (wk) }\end{array}$} & \multicolumn{2}{|c|}{ Liver } & \multicolumn{2}{|c|}{ Kidney } & \multicolumn{2}{|c|}{ Pancreas } \\
\hline & & CPM & SHV-DNA & CPM & SHV-DNA & $C P M$ & SHV-DNA \\
\hline Rainbow trout & 2 & 21 & 7 & 11 & 3 & 53 & 14 \\
\hline \multirow[t]{6}{*}{ Alevin } & 3 & 123 & 32 & 100 & 26 & 103 & 27 \\
\hline & 4 & 816 & 214 & 161 & 43 & 532 & 137 \\
\hline & 5 & 373 & 48 & 167 & 44 & 177 & 46 \\
\hline & 6 & 125 & 33 & 53 & 14 & 98 & 26 \\
\hline & 20 & 77 & 20 & 41 & 11 & 52 & 14 \\
\hline & 35 & $<\mathrm{C}$ & 0 & $<\mathrm{C}$ & 0 & $<\mathrm{C}$ & 0 \\
\hline Rainbow trout & 2 & 15 & 4 & 2 & 1 & $<\mathrm{C}$ & 0 \\
\hline \multirow[t]{6}{*}{ Juveniles } & 3 & 29 & 8 & 14 & 4 & 68 & 18 \\
\hline & 4 & 220 & 58 & 94 & 25 & 197 & 52 \\
\hline & 5 & 203 & 53 & 44 & 12 & 233 & 61 \\
\hline & 6 & 63 & 17 & 11 & 3 & 33 & 9 \\
\hline & 16 & 48 & 13 & 24 & 6 & 20 & 5 \\
\hline & 31 & $<\mathrm{C}$ & 0 & $<\mathrm{C}$ & 0 & $<\mathrm{C}$ & 0 \\
\hline Chinook salmon & 1 & 8 & 3 & 3 & 1 & 7 & 2 \\
\hline \multirow[t]{6}{*}{ Alevin } & 2 & 7 & 2 & 1 & 0.4 & 9 & 3 \\
\hline & 3 & 133 & 40 & 87 & 26 & 131 & 39 \\
\hline & 4 & 478 & 143 & 104 & 32 & 290 & 87 \\
\hline & 5 & 506 & 151 & 141 & 42 & 306 & 91 \\
\hline & 6 & 106 & 32 & 61 & 18 & 59 & 18 \\
\hline & 10 & 67 & 20 & 55 & 16 & 41 & 12 \\
\hline
\end{tabular}

there is no clear epizootiologic pattern indicating a spread of HPV from Washington State, it is impossible to determine if SHV is a low virulent strain of HPV, which, over time spread to salmonids in California. It must also be considered that no connection may exist between SHV and HPV and that the 2 viruses have separate or very distant common origins. It is possible that SHV has been present in California much longer than its first isolation in 1985, but that it was not detected due to its stringent temperature requirements, the long incubation period needed for primary isolation, and the limited pathologic response induced in fish. Whether SHV is present in other western states is unknown. The Alaska Department of Fish and Game is the only other agency that has tried (unsuccessfully) to isolate the virus from steelhead trout. The California Department of Fish and Game is continuing to monitor Californian populations of salmonids for SHV in order to better understand its geographic distribution.

Acknowledgements. This work was supported in part by Wallop-Breaux funds administered by the California Department of Fish and Game. The assistance and cooperation of CDFG was greatly appreciated. Special thanks are due to Royce Gunter and the staff at the Warm Springs Hatchery for their assistance in this endeavor

\section{LITERATURE CITED}

Brandsma, J., Miller, G. (1980). Nucleic acid spot hybridization. rapid quantitative screening o lymphoid cell lines for Epstein-Barr viral DNA. Proc. Nat. Acad. Sci. U.S.A. 77 : $6851-6855$

Eaton, W. D. (1988). Characteristics of the steelhead herpesvirus. Ph. D. Dissertation. University of California, Davis, California

Fijan, N. N. (1968). Progress report on acute mortality of channel catfish fingerlings caused by a virus. Bull. Off. Int. Epizoo. 69: 1167-1168

Hedrick, R. P., Leong, J. C., Fryer, J. L. (1978). Persistent infections in salmonid fish cells with infectious pancreatic necrosis vius (IPNV). J. Fish Dis. 1: 297-308

Hedrick, R. P., McDowell, T., Eaton, W. D., Chan, L., Wingfield, W. (1986). Herpesvirus salmonis: First occurence in anadromous salmonids. Bull. Fish. Path. 6 (3): 66-68

Hedrick, R. P., McDowell, T., Eaton, W D., Wingfield, W. (1987). Serologic relationships of five herpesviruses isolated from salmonids. J. Appl. Ichthyol. 3: 87-92.

Humason, G. L. 1979. Animal Tissue Techniques. W. H. Freeman \& Co. San Fancisco, California

Kimura, T., Yoshimizu, M., Tanaka, M., Sannohe, H. (1981). Studies on a new virus (OMV) from Oncorhynchus masou. I. Characteristics and pathogenicity. Fish Path. 15 (3/4): $143-147$

Maniatis, T., Fritsch, E. F., Sambrook, J. (1982). Molecular cloning. A laboratory manual. Cold Springs Harbor Laboratory, Cold Spring Harbor, N.Y 
Okamoto, N., Sano, T., Hedrick, R. P., Fryer, J, L. (1983). Antigenic relationships of selected strains of infectious pancreatic necrosis virus and eel virus european. J. Fish Dis. 6: 19-25

Roizman, B. (1982). The family Herpesviridae. General description, taxonomy and classification. In: Roizman, B. (ed.) The viruses, Vol. 1. Herpesviruses. Plenurn Press, New York p. $1-23$

Sano, T. (1976). Viral diseases of cultured fishes in Japan. Fish Path. $10(2): 221-226$

Sano, T., Fukuda, H., Okamoto, N., Kaneko, F. (1983). Yamame Tumor Virus: lethality and oncogenicity. Bull. Jap. Soc. Sci. Fish. 49 (8): 1159-1163

Responsible Subject Editor: Dr T Evelyn, Nanaimo, B.C., Canada
Wolf, K., Herman, R. L., Darlington, R., Taylor, W. G. (1975a). Salmonid viruses: effects o Herpesvirus salmonis in rainbow trout fry. Fish Hlth News 4 (8): 8

Wolf, K., Nagabayashi, T., Quimby, M. C. 1975. Herpesvirus salmonis: tests of species susceptibility, suggestions for isolation, geographic distribution and control measures. Fish H.th News. 4 (4): 6-7

Wolf, K., Smith, C. E. (1981). Herpesvirus salmonis: pathological changes in parenterally-infected rainbow trout, Salmo gairdneri Richardson, fry. J. Fish Dis, 4: 445-457

Wolf, K., Taylor, T (1975). Salmonid viruses: a syncytiumforming agent from rainbow trout. Fish Hlth News 4: 6-7

Manuscript first received: November 14, 1988

Revised version accepted: June 22, 1989 